Syntax Literate : Jurnal Ilmiah Indonesia p-ISSN: 2541-0849

e-ISSN : 2548-1398

Vol. 5, No. 1 Januari 2020

\title{
EVALUASI PENGGUNAAN OBAT KELASI BESI DALAM MENURUNKAN KADAR FERRITIN PADA PASIEN THALASEMIA ANAK DI RSUD 45 KUNINGAN
}

\author{
Cece Supriatna, Bambang Karsidin Indriani dan Ratih Akbari \\ Prodi Profesi Apoteker dan Prodi Sarjana Farmasi STF YPIB Cirebon \\ Email: cecesupriatna72@gmail.com,bambangkarsidin@yahoo.co.id dan \\ rthindriani@gmail.com
}

\begin{abstract}
Abstrak
Tujuan dari penelitian ini adalah mengetahui kadar ferritin pada pasien Thalasemia anak di RSUD 45 Kuningan saat pertama kali didiagnosa menderita Thalasemia dan mengetahui ada atau tidaknya penurunan kadar ferritin setelah pasien diberikan terapi obat kelasi besi. Populasi yang digunakan adalah pasien Thalasemia di RSUD 45 Kuningan, dengan sampel sebanyak 46 pasien. Setelah melakukan penelitian, pengolahan data dan wawancara diperoleh hasil bahwa kadar ferritin pasien Thalasemia anak ketika pertama kali didiagnosa menderita Thalasemia adalah $>500 \mathrm{mcg} / \mathrm{L}$, dari 46 pasien yang dijadikan sampel, 5 orang mengalami penurunan kadar ferritin dengan baik, 8 orang mengalami penurunan di 3 bulan pertama tetapi naik kembali di 3 bulan selanjutnya, sedangkan 33 pasien lainnya cenderung tidak mengalami penurunan kadar ferritin. Hasil penelitian tersebut semoga menjadi perhatian bagi semua bagian yang terkait agar tujuan pengobatan pada pasien Thalasemia anak di RSUD 45 Kuningan bisa tercapai.
\end{abstract}

Kata kunci: Kadar Ferritin, Obat Kelasi Besi, Thalasemia

\section{Pendahuluan}

Pengaruh era globalisasi di segala bidang, perkembangan teknologi dan industri mengakibatkan perubahan pada perilaku dan gaya hidup masyarakat serta situasi lingkungan, seperti perubahan terhadap pola konsumsi makanan yang serba instan, serta perkembangan dunia teknologi dan komunikasi yang semakin meninggi membuat manusia seakan enggan untuk bergerak dan berolahraga (Subandi, 2017).

Thalasemia adalah suatu gangguan darah yang diturunkan ditandai oleh defisiensi produk rantai globulin pada hemoglobin (Susanto \& Suryadi, 2010). Penyakit thalasemia merupakan salah satu penyakit genetik terbanyak di dunia. Penyakit genetik ini diakibatkan oleh ketidak mampuan sumsum tulang membentuk protein yang dibutuhkan untuk memproduksi hemoglobin (Mandleco \& Potts, 2007) Hemoglobin merupakan protein kaya zat besi yang berada didalam sel darah merah yang berfungsi untuk mengangkut oksigen dari paru-paru ke seluruh bagian tubuh.

Badan kesehatan dunia atau WHO (2012) menyatakan kurang lebih 7\% dari penduduk dunia mempunyai gen thalasemia dimana angka kejadian tertinggi sampai dengan $40 \%$ adalah di Asia. Gejala awal yang muncul pada penderita thalasemia antara 
lain pucat, lemas, dan tidak nafsu makan (Swayze, Hoffman, Stefanchik, Goldin, \& Nobis, 2003). Pada kasus yang lebih berat pasien thalasemia menunjukkan gejala klinis berupa hepatosplenomegali, kerapuhan, penipisan tulang dan anemia. Anemia pada pasien thalasemia terjadi akibat gangguan produksi hemoglobin.

Gejala anemia pada anak thalasemia sudah dapat terlihat pada usia kurang dari 1 tahun. Derajat anemia yang terjadi dapat bervariasi dari ringan sampai berat. Anemia merupakan masalah utama pada thalasemia dan dapat diatasi dengan memberikan transfusi darah. Transfusi darah bertujuan untuk mempertahankan kadar hemoglobin 9$10 \mathrm{~g} / \mathrm{dl}$ (Rahayu, 2012) Akan tetapi pemberian transfusi darah secara terus menerus akan menyebabkan terjadinya penumpukan besi pada jaringan parenkim hati dan disertai dengan serum besi dan ferritin yang tinggi.

Ferritin merupakan protein dalam tubuh yang mengikat zat besi. Sebagian besar zat besi yang tersimpan dalam tubuh terikat dengan protein tersebut. Zat besi bebas bersifat toksik atau berbahaya bagi sel, tubuh memiliki mekanisme perlindungan untuk mengikat zat besi bebas tersebut. Di dalam sel, zat besi disimpan dalam bentuk ikatan dengan protein ferritin. Oleh karena itu, ferritin berfungsi menyimpan zat besi dalam bentuk terlarut dan non toksik. Kadar ferritin dalam serum darah berkorelasi dengan jumlah total simpanan zat besi tubuh sehingga pengukuran ferritin serum adalah pemeriksaan laboratorium yang paling mudah untuk memperkirakan status simpanan zat besi.

Darah terdiri dari beberapa beberapa bagian seperti gambar 1

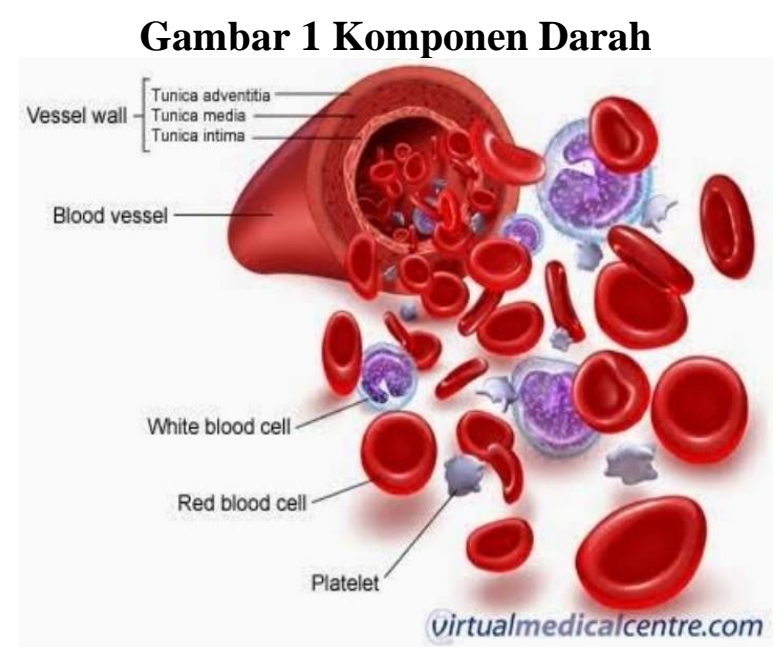

Kelasi besi adalah obat obatan yang ditujukan untuk mengurangi kadar zat besi dalam darah terutama ferritin. Fungsi dari kelasi besi ini adalah menurunkan jumlah ferritin dan serum iron dalam darah supaya tidak mengganggu kerja organ organ vital dalam tubuh. macam-macam obat kelasi besi adalah :

1. Ferriprox (Deferiprone)

2. Desferal (Deferoxamine)

3. Exjade (Deferasirox) 
Terapi Deferasirox dapat dipertimbang kan jika pasien memilik serum feritin lebih besar dari $300 \mathrm{mcg} / \mathrm{L}$. Selain obat obat kelasi besi, pasien Thalasemia juga membutuhkan suplemen asam folat 1-2 gram/hari untuk membantu meningkatkan kadar hemoglobin, vitamin E 200-400 IU / hari untuk memperpanjang umur sel darah merah dan Vitamin C 100-250 mg / hari untuk meningkatkan ekskresi zat besi.

\section{Metode Penelitian}

Desain penelitian yang digunakan adalah deskriptif analitik dengan pendekatan cross sectional, dimana pengukuran variabelnya dilakukan hanya satu kali. Studi cross sectional mempelajari hubungan antara variabel bebas (faktor resiko) dengan variabel tergantung (efek) dengan pengukuran sesaat. Variabel resiko serta efek tersebut diukur menurut keadaan statusnya pada waktu observasi (Sastroasmoro \& Ismael, 2010)

Dalam penelitian ini, jumlah populasi pasien thalasemia anak sebanyak 85 orang dan batas toleransi kesalahan adalah 10\%, maka sampel yang diperoleh berdasarkan rumus Slovin adalah :

$$
\mathrm{n}=\frac{85}{1+85(0.1)^{2}}
$$

$\mathrm{n}=45,9$ atau 46 orang

Sampel sebanyak 46 pasien yaitu pasien pengguna Deferiprone / Ferriprox sebanyak 23 orang dan pasien pengguna Deferasirox / Exjade sebanyak 23 orang dan pemilihannya dilakukan secara random / acak. Langkah langkah pengumpulan data dalam penelitian ini meliputi prosedur administrative dan prosedur tekhnis (Sastroasmoro \& Ismael, 2010).

1. Mencatat identitas pasien thalasemia anak yang akan dijadikan sampel penelitian, meliputi : nama, nomor rekam medis / medical record, tanggal didiagnosa Thalasemia, tanggal pertama melakukan transfusi darah, jenis obat kelasi besi yang digunakan dan dosis obat.

2. Mencatat kadar ferritin kadar ferritin awal sebelum melakukan pengobatan, kadar ferritin 3 bulan pertama setelah minum obat kelasi besi, kadar ferritin 3 bulan kedua dan 3 bulan ketiga setelah minum obat kelasi besi.sesuai data dalam medical record pasien.

\section{Hasil dan Pembahasan}

Jumlah sampel yang digunakan dalam penelitian ini adalah 46 pasien Thalasemia anak, yaitu pengguna obat kelasi besi Ferriprox (Deferiprone) sebanyak 23 pasien dan pengguna obat kelasi besi Exjade (Deferasirox) sebanyak 23 pasien.

Penelitian yang dilakukan oleh Dahlui, Hishamsah, Rahman dan Aljunid (2009) di malaysia menemukan bahwa kualitas hidup pasien thalasemia berhubungan dengan kadar feritin, komplikasi kelebihan zat besi, dan penghasilan keluarga. Penelitian yang berkaitan dengan kualitas hidup anak thalasemia di Indonesia sudah pernah dilakukan di semarang oleh Bulan (2009), menemukan beberapa faktor yang mempengaruhi kualitas 
hidup anak thalasemia diantaranya adalah kadar $\mathrm{Hb}$, jenis kelasi besi dan kadar feritin dalam darah.

Berdasarkan penurunan kadar ferritin setelah menggunakan obat kelasi besi, sampel dibagi menjadi 6 kelompok, yaitu:

1. Kelompok A yaitu kelompok pasien pengguna Ferriprox (Deferiprone) yang menunjukkan penurunan kadar ferritin dengan baik, sebanyak 2 pasien atau 8,70\%.

2. Kelompok B yaitu kelompok pasien pengguna Ferriprox (Deferiprone) yang menunjukkan penurunan kadar ferritin di 3 bulan pertama tapi kembali naik di 3 bulan kedua, sebanyak 4 pasien atau $17,40 \%$

3. Kelompok $\mathrm{C}$ yaitu kelompok pasien pengguna Ferriprox (Deferiprone) yang tidak menunjukkan penurunan kadar ferritin, sebanyak 17 pasien atau 73,90\%.

4. Kelompok D yaitu kelompok pasien pengguna Exjade (Deferasirox) yang menunjukkan penurunan kadar ferritin dengan baik.

5. Kelompok E yaitu kelompok pasien pengguna Exjade (Deferasirox) yang menunjukkan penurunan kadar ferritin di 3 bulan pertama tapi kembali naik di 3 bulan kedua.

6. Kelompok F yaitu kelompok pasien pengguna Exjade (Deferasirox) yang tidak menunjukkan penurunan kadar ferritin.

Tabel 1

Data Pasien Pengguna Obat Ferriprox (Deferiprone) kelompok A

\begin{tabular}{c|c|c|c|c|c|c|c}
\hline No & $\begin{array}{c}\text { Nama } \\
\text { Pasien / } \\
\text { No. Medrec }\end{array}$ & $\begin{array}{c}\text { Jenis } \\
\text { Obat } \\
\text { Kelasi } \\
\text { Besi }\end{array}$ & $\begin{array}{c}\text { Dosis } \\
\text { Obat }\end{array}$ & $\begin{array}{c}\text { Kadar } \\
\text { Feritin } \\
\text { Awal }\end{array}$ & $\begin{array}{c}\text { Kadar Feri } \\
\text { tin 3 Bulan } \\
\text { Perta } \\
\text { ma }\end{array}$ & $\begin{array}{c}\text { Kadar } \\
\text { Feri } \\
\text { tin 3 } \\
\text { Bulan } \\
\text { Kedua }\end{array}$ & $\begin{array}{c}\text { Kadar Feri } \\
\text { tin 3 Bulan } \\
\text { Selan jut } \\
\text { nya }\end{array}$ \\
\hline A & B & E & F & G & H & I & J \\
\hline 1. & Vira & $\begin{array}{c}\text { Ferri } \\
\text { Prox }\end{array}$ & $\begin{array}{c}3 \times 2 \\
\text { tab }\end{array}$ & 7967 & 6948 & 6742 & 5501 \\
\hline 2. & Shelly & $\begin{array}{c}\text { Ferri } \\
\text { Prox }\end{array}$ & $\begin{array}{c}3 \times 2 \\
\text { tab }\end{array}$ & 2920 & 2192 & 1825 & 1262 \\
\hline
\end{tabular}

Tabel 2

Data Pasien Pengguna Obat Ferriprox (Deferiprone) Kelompok B

\begin{tabular}{|c|c|c|c|c|c|c|c|}
\hline No & $\begin{array}{c}\text { Nama } \\
\text { Pasien / } \\
\text { No. } \\
\text { Medrec }\end{array}$ & $\begin{array}{c}\text { Jenis } \\
\text { Obat } \\
\text { Kelasi } \\
\text { Besi }\end{array}$ & $\begin{array}{c}\text { Do } \\
\text { sis Obat }\end{array}$ & $\begin{array}{c}\text { Ka } \\
\text { dar } \\
\text { Feri } \\
\text { tin } \\
\text { awal }\end{array}$ & $\begin{array}{c}\text { Kadar } \\
\text { Feri } \\
\text { tin } 3 \\
\text { Bulan } \\
\text { Per } \\
\text { tama }\end{array}$ & $\begin{array}{c}\text { Kadar } \\
\text { Feri } \\
\text { tin } 3 \\
\text { Bulan } \\
\text { Ke } \\
\text { dua }\end{array}$ & $\begin{array}{c}\text { Kadar } \\
\text { Feri } \\
\text { tin } 3 \\
\text { Bulan } \\
\text { Selan } \\
\text { jutnya }\end{array}$ \\
\hline A & B & $\mathrm{E}$ & $\mathrm{F}$ & G & $\mathrm{H}$ & I & $\mathrm{J}$ \\
\hline 1. & M. Nabil & $\begin{array}{l}\text { Ferri } \\
\text { prox }\end{array}$ & $3 \times 2$ tab & 2234 & 2050 & 3310 & 2059 \\
\hline 2. & $\begin{array}{c}\text { Nur Afni } \\
\text { Okta } \\
\text { vin }\end{array}$ & $\begin{array}{l}\text { Ferr } \\
\text { iprox }\end{array}$ & $3 \times 2$ tab & 4704 & 2285 & 3921 & 3510 \\
\hline
\end{tabular}




\begin{tabular}{c|c|c|c|c|c|c|c}
\hline 3. & $\begin{array}{c}\text { Nizam } \\
\text { Alfarizi }\end{array}$ & $\begin{array}{c}\text { Ferri } \\
\text { prox }\end{array}$ & $3 \times 1$ tab & 1946 & 948 & 1718 & 1680 \\
\hline 4. & $\begin{array}{c}\text { Yuda M } \\
\text { Zaemali }\end{array}$ & $\begin{array}{c}\text { Ferri } \\
\text { prox }\end{array}$ & $3 \times 2$ tab & 4543 & 1468 & 2005 & 1708 \\
\hline
\end{tabular}

Tabel 3

Data Pasien Pengguna Obat Ferriprox (Deferiprone) Kelompok C

\begin{tabular}{c|c|c|c|c|c|c|c}
\hline No & $\begin{array}{c}\text { Namasien / No. } \\
\text { Medrec }\end{array}$ & $\begin{array}{c}\text { Jenis Obat } \\
\text { Kelasi } \\
\text { Besi }\end{array}$ & $\begin{array}{c}\text { Dosis } \\
\text { Obat }\end{array}$ & $\begin{array}{c}\text { Kadar } \\
\text { Feri } \\
\text { tin Awal }\end{array}$ & $\begin{array}{c}\text { Ka } \\
\text { dar Feri } \\
\text { tin 3 Bu } \\
\text { lan } \\
\text { Pertama }\end{array}$ & $\begin{array}{c}\text { Ka } \\
\text { ar } \\
\text { Feriti } \\
\text { n 3 } \\
\text { Bu } \\
\text { lan Ke } \\
\text { dua }\end{array}$ & $\begin{array}{c}\text { Ka } \\
\text { far } \\
\text { Feriti } \\
\text { n 3 } \\
\text { Bu } \\
\text { lan } \\
\text { Selanj } \\
\text { utnya }\end{array}$ \\
\hline A & B & E & F & G & H & I & J \\
\hline 1. & Haidar Mahasin & Ferriprox & $3 \times 1$ cth & 2829 & 5168 & 4007 & 4126 \\
\hline 2. & M. Dzikri & Ferriprox & $3 \times 1$ tab & 2752 & 6339 & 2049 & 3873 \\
\hline 3. & Novi Yanti & Ferriprox & $3 \times 2$ tab & 1934 & 2009 & 2657 & 3079 \\
\hline 4. & Iryad Firmn Syah & Ferriprox & $3 \times 2$ tab & 3419 & 3876 & 4421 & 6467 \\
\hline 5. & Vera Olivia & Ferriprox & $3 \times 2$ tab & 1330 & 1330 & 1486 & 1773 \\
\hline 6. & Rizky Nur Fajar & Ferriprox & $3 \times 1$ tab & 1441 & 1972 & 1141 & 1427 \\
\hline 7. & Reyhan Rizky & Ferriprox & $3 \times 2$ tab & 2412 & 2577 & 3257 & 3878 \\
\hline 8. & Risky Wahyuni & Ferriprox & $3 \times 2$ tab & 3874 & 3801 & 3098 & 3627 \\
\hline 9. & Ratna Sumiar & Ferriprox & $3 \times 2$ tab & 1949 & 1960 & 2164 & 3264 \\
\hline 10. & Rania Aqila & Ferriprox & $3 \times 2 \mathrm{cth}$ & 1601 & 1794 & 2226 & 2491 \\
\hline 11. & Rafa R & Ferriprox & $3 \times 1$ tab & 3457 & 4955 & 7129 & 4031 \\
\hline 12. & Rizqy Langit & Ferriprox & $3 \times 2$ tab & 1264 & 1261 & 5097 & 802 \\
\hline 13. & Rafif & Ferriprox & $3 \times 2$ tab & 1358 & 1226 & 1314 & 1369 \\
\hline 14. & Stephani & Ferriprox & $3 \times 1 \mathrm{cth}$ & 7719 & 8040 & 7012 & 8035 \\
\hline 15. & Syifa Nadira & Ferriprox & $3 \times 1 \mathrm{cth}$ & 5362 & 7590 & 4953 & 5295 \\
\hline 16. & Febriansyah & Ferriprox & $3 \times 1$ tab & 3791 & 3739 & 3178 & 3463 \\
\hline 17. & Fahri & Ferriprox & $3 \times 2$ tab & 2148 & 2857 & 3265 & 3630
\end{tabular}

Diagram lingkaran untuk hasil pengamatan kadar ferritin pada pasien pengguna obat Ferriprox (Deferiprone) adalah sebagai berikut: 
Diagram 1

Data Pasien Thalasemia Anak Pengguna Ferriprox (Deferiprone)

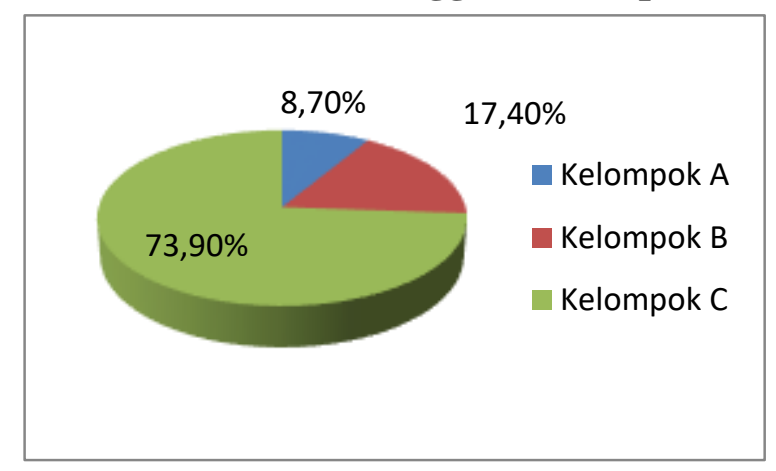

Tabel 4

Data Pasien Pengguna Obat Exjade (Deferasirox) Kelompok D

\begin{tabular}{c|c|c|c|c|c|c|c}
\hline No & $\begin{array}{c}\text { Nama } \\
\text { Pasien / } \\
\text { No. Medrec }\end{array}$ & $\begin{array}{c}\text { Jenis } \\
\text { Obat } \\
\text { Besiasi }\end{array}$ & $\begin{array}{c}\text { Dosis } \\
\text { Obat }\end{array}$ & $\begin{array}{c}\text { Kadar } \\
\text { Feriti } \\
\mathrm{n} \\
\text { Awal }\end{array}$ & $\begin{array}{c}\text { Kadar } \\
\text { Feritin 3 } \\
\text { Bulan } \\
\text { Pertama }\end{array}$ & $\begin{array}{c}\text { Kadar } \\
\text { Feriti } \\
\text { Bulan } \\
\text { Kedua }\end{array}$ & $\begin{array}{c}\text { Kadar } \\
\text { Feritin } \\
\text { 3 Bulan } \\
\text { Selanju } \\
\text { tnya }\end{array}$ \\
\hline A & B & E & F & G & H & I & J \\
\hline 1. & M. Imdad D & Exjade & $\begin{array}{c}1 \times 2 \\
\text { tab }\end{array}$ & 7592 & 5816 & 5722 & 5678 \\
\hline 2. & $\begin{array}{c}\text { Alya } \\
\text { Ramdhani }\end{array}$ & Exjade & $\begin{array}{c}1 \times 1 \\
\text { tab }\end{array}$ & 1985 & 1760 & 1511 & 1500 \\
\hline 3. & Alif Falih & Exjade & $\begin{array}{c}1 \times 1 \\
\text { tab }\end{array}$ & 4206 & 2678 & 1340 & 1210 \\
\hline
\end{tabular}

Tabel 5

Data Pasien Pengguna Obat Exjade (Deferasirox) Kelompok E

\begin{tabular}{c|c|c|c|c|c|c|c}
\hline No & $\begin{array}{c}\text { Nama } \\
\text { Pasien / } \\
\text { No. } \\
\text { Medrec }\end{array}$ & $\begin{array}{c}\text { Jenis } \\
\text { Kelasi } \\
\text { Besi }\end{array}$ & $\begin{array}{c}\text { Do } \\
\text { sis } \\
\text { Obat }\end{array}$ & $\begin{array}{c}\text { Ka } \\
\text { dar } \\
\text { Feri } \\
\text { tin } \\
\text { awal }\end{array}$ & $\begin{array}{c}\text { Kadar } \\
\text { Feri } \\
\text { tin 3 } \\
\text { Bulan } \\
\text { Pertama }\end{array}$ & $\begin{array}{c}\text { Kadar } \\
\text { Feri } \\
\text { tin 3 } \\
\text { Bulan } \\
\text { Ke } \\
\text { dua }\end{array}$ & $\begin{array}{c}\text { Kadar } \\
\text { Fulan 3 } \\
\text { Selan } \\
\text { jutnya }\end{array}$ \\
\hline A & B & E & $\mathrm{F}$ & $\mathrm{G}$ & $\mathrm{H}$ & $\mathrm{I}$ & $\mathrm{J}$ \\
\hline 1. & $\begin{array}{c}\text { Dinda } \\
\text { Afifah }\end{array}$ & Exjade & $\begin{array}{c}1 \mathrm{x} 2 \\
\mathrm{tab}\end{array}$ & 1655 & 889 & 2355 & 878 \\
\hline 2. & M. Fardan & Exjade & $\begin{array}{c}1 \mathrm{x} 2 \\
\text { tab }\end{array}$ & 1466 & 1369 & 2081 & 1337,92 \\
\hline 3. & M. Rizky & Exjade & $\begin{array}{c}1 \mathrm{x} 2 \\
\mathrm{tab}\end{array}$ & 1354 & 1235 & 1635 & 1383 \\
\hline 4. & $\begin{array}{c}\text { Mawar } \\
\text { Wulansari }\end{array}$ & Exjade & $\begin{array}{c}1 \mathrm{x} 2 \\
\mathrm{tab}\end{array}$ & 3402 & 3234 & 4117 & 3907 \\
\hline
\end{tabular}


Tabel 6

Data Pasien Pengguna Obat Exjade (Deferasirox) Kelompok F

\begin{tabular}{|c|c|c|c|c|c|c|c|}
\hline No & $\begin{array}{c}\text { Nama } \\
\text { Pasien / } \\
\text { No. } \\
\text { Medrec }\end{array}$ & $\begin{array}{c}\text { Jenis } \\
\text { Obat } \\
\text { Kelasi } \\
\text { Besi }\end{array}$ & $\begin{array}{c}\text { Dosis } \\
\text { Obat }\end{array}$ & $\begin{array}{c}\text { Kadar } \\
\text { Feritin } \\
\text { awal }\end{array}$ & $\begin{array}{c}\text { Kadar } \\
\text { Feri } \\
\text { tin } 3 \\
\text { Bulan } \\
\text { Pertama }\end{array}$ & $\begin{array}{c}\text { Kadar Feri } \\
\text { tin } 3 \text { Bulan } \\
\text { Ke dua }\end{array}$ & $\begin{array}{c}\text { Kadar Feri } \\
\text { tin } 3 \text { Bulan } \\
\text { Selan } \\
\text { jutnya }\end{array}$ \\
\hline $\mathrm{A}$ & B & $\mathrm{E}$ & $F$ & $\mathrm{G}$ & $\mathrm{H}$ & $\mathrm{I}$ & $\mathrm{J}$ \\
\hline 1. & Al Rizky & Exjade & $1 \times 2 \mathrm{tab}$ & 1238 & 1732 & 1861 & 2039 \\
\hline 2. & Aida & Exjade & $1 \times 2 \mathrm{tab}$ & 5509 & 8575 & 7983 & 8140 \\
\hline 3. & Andres J & Exjade & $1 \times 2 \mathrm{tab}$ & 6995 & 9701 & 8717 & 8819 \\
\hline 4. & $\begin{array}{c}\text { Arikan } \\
\text { Zul }\end{array}$ & Exjade & $1 \times 2$ tab & 5027 & 6625 & 5114 & 4846 \\
\hline 5. & Aftar & Exjade & $1 \times 1 \mathrm{tab}$ & 1305 & 1333 & 1429 & 1528 \\
\hline 6. & Ardan & Exjade & $1 \times 2 \mathrm{tab}$ & 1322 & 1322 & 1365 & 2145 \\
\hline 7. & $\begin{array}{c}\text { Bang } \\
\text { Kit }\end{array}$ & Exjade & $1 \times 2$ tab & 1840 & 2556 & 3242 & 3652 \\
\hline 8. & Candy & Exjade & $1 \times 2 \mathrm{tab}$ & 5585 & 5741 & 5673 & 8998 \\
\hline 9. & $\begin{array}{l}\text { Daffa } \\
\text { Sigit }\end{array}$ & Exjade & $1 \times 2$ tab & 39778 & 4644 & 11921 & 5125 \\
\hline 10. & $\begin{array}{l}\text { M. Adri } \\
\text { An }\end{array}$ & Exjade & $1 \times 1$ tab & 1621 & 2205 & 2808 & 3228 \\
\hline 11. & M. Fahry & Exjade & $1 \times 2$ tab & 1400 & 1873 & 2005 & 2030 \\
\hline 12. & $\begin{array}{c}\text { M. Azka } \\
\text { T }\end{array}$ & Exjade & $1 \times 2$ tab & 2705,98 & 2572,48 & 3806 & 4129 \\
\hline 13. & $\begin{array}{c}\text { M. Azka } \\
\text { Q }\end{array}$ & Exjade & $1 \times 2$ tab & 2559 & 2951 & 1965 & 3221 \\
\hline 14. & Maureen & Exjade & $1 \times 1$ tab & 8980 & 8836 & 9760 & 9034 \\
\hline 15. & $\begin{array}{c}\text { M. } \\
\text { Fahmi }\end{array}$ & Exjade & $1 \times 2$ tab & 4932 & 4984 & 3766 & 6691 \\
\hline 16. & $\begin{array}{c}\text { M. } \\
\text { Fahmi } \\
\text { Kaisan } \\
\end{array}$ & Exjade & $1 \times 2$ tab & 1932 & 2984 & 3766 & 6691 \\
\hline
\end{tabular}

Diagram lingkaran untuk hasil pengamatan kadar ferritin pada pasien pengguna obat Exjade (Deferasirox) adalah sebagai berikut: 


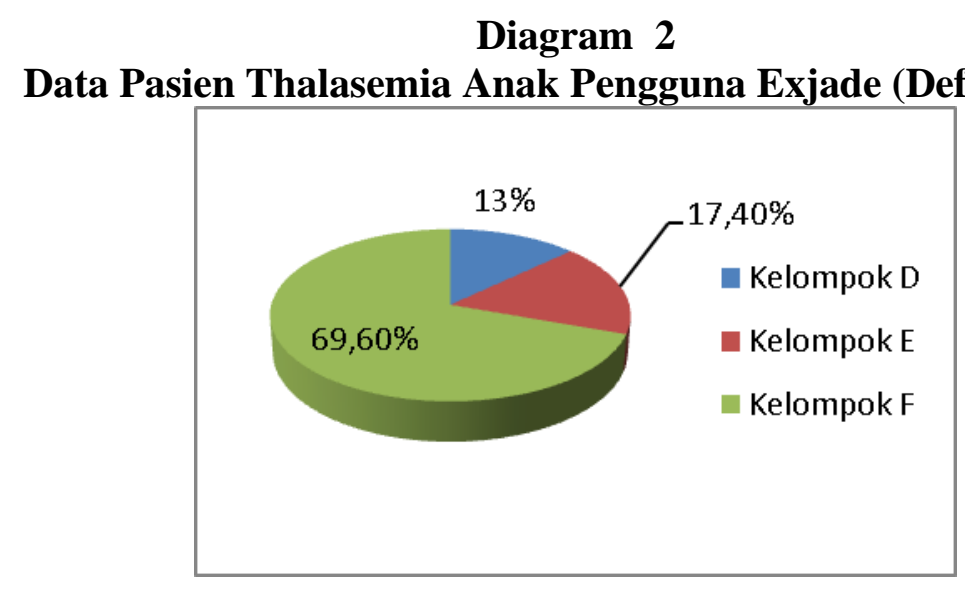

Ketiga kelompok diatas adalah:

1. Kelompok D adalah kelompok pasien pengguna Exjade (Deferasirox) yang menunjukkan penurunan kadar ferritin dengan baik sebanyak 3 pasien atau $13 \%$.

2. Kelompok E adalah kelompok pasien pengguna Exjade (Deferasirox) yang menunjukkan penurunan kadar ferritin di 3 bulan pertama tapi kembali naik di 3 bulan kedua sebanyak 4 pasien atau 17,40\%.

3. Kelompok $\mathrm{F}$ adalah kelompok pasien pengguna Exjade (Deferasirox) yang tidak menunjukkan penurunan kadar ferritin sebanyak 16 pasien atau $69,60 \%$

Obat kelasi besi yang ada di RSU 45 Kuningan ada 3 macam, yaitu Ferriprox (Deferiprone), Exjade (Deferasirox) dan Desferal (Deferoxamine), pada penelitian ini pengamatan hanya dilakukan pada pasien Thalasemia anak yang menggunakan obat kelasi besi Ferriprox (Deferiprone) dan Exjade (Deferasirox). Penggunaan kelasi besi desferal (Deferoxamine) tidak rutin digunakan setiap hari, hanya diberikan pada pasien Thalasemia dengan kadar ferritin lebih dari $10.000 \mathrm{mcg} / \mathrm{L}$ dengan cara disuntikkan. Dosis pemberian Desferal adalah $40 \mathrm{mg} / \mathrm{kg} /$ hari selama 5 hingga 7 hari setiap minggunya. Desferal bekerja dengan mengikat zat besi dan mengubahnya menjadi ferrioxamine yang merupakan kompleks stabil sehingga akan mudah dikeluarkan oleh ginjal. Deferoxamine dimetabolisme di enzim plasma dan beberapa diekskresikan ke tinja dan urin.

Standar Prosedur Operasional (SPO) di Klinik Thalasemia RSUD 45 Kuningan untuk pasien thalasemia anak yang pertama adalah pemeriksaan Hemoglobin $(\mathrm{Hb})$ karena pasien Thalasemia yang cenderung anemis, terapi selanjutnya adalah transfusi darah yang dilakukan minimal satu bulan sekali tergantung kondisi Hemoglobin $(\mathrm{Hb})$ pasien. Obat kelasi besi diberikan setelah pasien 5 kali mendapatkan transfusi darah, kemudian selanjutnya rutin diberikan setiap 1 bulan sekali. Selain pemberian obat kelasi besi yaitu Ferriprox (Deferiprone) atau Exjade (Deferasirox) biasanya diberikan juga vitamin E dan asam folat. Sementara obat injeksi yaitu Desferal (Deferoxamine) hanya diberikan pada pasien yang kadar ferritinnya mencapai $10.000 \mathrm{mcg} / \mathrm{L}$ untuk mencegah keracunan zat besi secara cepat. 
Berdasarkan hasil wawancara dengan keluarga pasien, diperoleh informasi mengapa sebagian besar pasien tidak mengalami penurunan ferritin atau bahkan cenderung meningkat

1. Kepatuhan dan pengetahuan pasien dalam meminum obat, dari 46 pasien yang dijadikan sampel, 8 orang menyatakan enggan minum obat kelasi besi karena efek samping obat yang bisa menyebabkan mual dan pusing. 5 orang pasien merasa pengobatan cukup dengan transfusi darah, 5 pasien lainnya menyatakan obat kelasi besi hanya diminum saat mereka merasa lemas. Ketidak tahuan pasien terhadap pentingnya minum obat kelasi besi menjadi salah satu penyebab tidak tercapainya tujuan pengobatan.

2. Tidak adanya dukungan dan motivasi keluarga, selain pengetahuan tentang pentingnya minum obat kelasi besi, pasien Thalasemia juga membutuhkan perhatian dan dukungan dari keluarga dan lingkungan untuk bisa minum obat dengan teratur. Peran orang tua sangat dibutuhkan, terutama karena usia mereka yang masih kecil sehingga orang tualah yang harus mengingatkan pada jam jam minum obat.

3. Ketersediaan obat yang terbatas, yaitu jumlah persediaan obat kelasi besi yang tidak sebanding dengan jumlah pasien Thalasemia seringkali menjadi penyebab pasien tidak bisa mendapatkan obat untuk dikonsumsi, terkadang pasien mengurangi sendiri dosis obat yang diminum supaya jika obat di rumah sakit habis mereka masih bisa meminumnya meskipun tidak sesuai dosis yang dianjurkan dokter. Mahalnya harga obat membuat mereka tidak mampu untuk membeli obat sendiri saat obat tidak tersedia di rumah sakit.

4. Aturan penyelenggara kesehatan/ BPJS yaitu harus menyertakan surat protokol terapi setiap mengambil obat ke apotek seringkali menjadi penyebab mereka tidak bisa mendapatkan obat yang dibutuhkan jika tidak menyertakan protokol terapi tersebut. Protokol terapi adalah surat bukti Pengobatan awal dari rumah sakit faskes 3, umunya pasien RSUD 45 Kuningan mendapatkan surat protokol terapi dari dokter spesialis hematologi anak di RS Cipto Mangunkusumo Jakarta atau RS Hasan Sadikin Bandung.

Dari analisa data terlihat bahwa kelompok A dan kelompok D berhasil mengalami penurunan ferritin dengan baik karena mereka rutin minum obat kelasi besi, kelompok B dan kelompok E mengalami penurunan ferritin di 3 bulan pertama tetapi kembali naik di 3 bulan selanjutnya meskipun sebagian besar menyatakan rutin minum obat, sedangkan kelompok $\mathrm{C}$ dan kelompok F sama sekali tidak mengalami penurunan ferritin bahkan cenderung naik, karena mereka tidak rutin minum obat kelasi besi dengan berbagai alasan.

\section{Kesimpulan}

Berdasarkan hasil pengamatan di Klinik Thalasemia RSUD 45 Kuningan, diperoleh kesimpulan bahwa kadar ferritin pada pasien Thalasemia anak setelah mendapatkan obat kelasi besi pada 46 pasien yang dijadikan sampel dapat dibagi dalam 6 kelompok, yaitu: 
1. Kelompok A yaitu kelompok pasien pengguna Ferriprox (Deferiprone) yang menunjukkan penurunan kadar ferritin dengan baik, sebanyak 2 pasien.

2. Kelompok B yaitu kelompok pasien pengguna Ferriprox (Deferiprone) yang menunjukkan penurunan kadar ferritin di 3 bulan pertama tapi kembali naik di 3 bulan kedua, sebanyak 4 pasien.

3. Kelompok $\mathrm{C}$ yaitu kelompok pasien pengguna Ferriprox (Deferiprone) yang tidak menunjukkan penurunan kadar ferritin, sebanyak 17 pasien.

4. Kelompok D yaitu kelompok pasien pengguna Exjade (Deferasirox) yang menunjukkan penurunan kadar ferritin dengan baik sebanyak 3 pasien.

5. Kelompok E yaitu kelompok pasien pengguna Exjade (Deferasirox) yang menunjukkan penurunan kadar ferritin di 3 bulan pertama tapi kembali naik di 3 bulan kedua sebanyak 4 pasien.

6. Kelompok F yaitu kelompok pasien pengguna Exjade (Deferasirox) yang tidak menunjukkan penurunan kadar ferritin sebanyak 16 pasien. 
Cece Supriatna, Bambang Karsidin Indriani dan Ratih Akbari

\section{BIBLIOGRAFI}

Bulan, S (2009), Faktor-faktor yang berhubungan dengan kualitas hidup anak thalasemia beta mayor, diperoleh dari http://eprint.undip.ac.id/247/ $\underline{\text { Sandra_Bulan.pdf }}$

Dahlui, M., Hishamsah, M.I., Rahman, A., \& Aljunid, S.M. (2009) Quality of life in transfusin dependent thalasemia patients on desferrioxamine treatment, Singapore Med J, 50 (8), 794-799. Diperoleh dari http://smj.sma.org.sg/5008/5008a8.pdf

Mandleco, B. L., \& Potts, N. L. (2007). Pediatric nursing: Caring for children and their families. Thomson Delmar Learning.

Rahayu, I. (2012). dkk. 2012. Panduan Lengkap Ayam. Penerbit. Penebar Swadaya, Jakarta.

Sastroasmoro, S., \& Ismael, S. (2010). Dasar-dasar Metodologi Penelitian Klinis Ed. 3 Cet. 2. Jakarta: Sagung Seto.

Subandi, E. (2017). Pengaruh Senam Diabetes Perhadap Penurunan Kadar Gula Darah Pada Pasien Diabetes Mellitus Di Upt Puskesmas Mundu Kabupaten Cirebon Tahun 2017. Syntax Literate; Jurnal Ilmiah Indonesia, 2(7), 53-68.

Susanto, S., \& Suryadi, D. (2010). Pengantar data mining: mengagali pengetahuan dari bongkahan data. Penerbit Andi.

Swayze, J. S., Hoffman, D. B., Stefanchik, D., Goldin, M. A., \& Nobis, R. H. (2003, March 11). Anastomosis device having improved tissue presentation. Google Patents.

WHO. (201), The global burden of disease up date. Diperoleh dari www.who.int/healthinfo/global_burder_disease/GBD_report_2004update_full.pdf 